\title{
Research Article \\ Effect of non-genetic factors on prolificacy and pre-weaning kid mortality of Khari goats in Nawalpur, Nepal
}

\author{
Nirajan Bhattarai \\ Department of Animal Breeding and Biotechnology, Faculty of Animal Science, Veterinary Science \\ and Fisheries, Agriculture and Forestry University, Rampur, Chitwan, Nepal \\ Correspondence: nbhattarai@afu.edu.np \\ ORCID: https://orcid.org/0000-0003-0325-6506 \\ Received: September 13, 2020; Accepted: November 16, 2020; Published: January 01, 2021 \\ (C) Copyright: Bhattarai (2021). \\ (c) (1) \& 8 This work is licensed under a Creative Commons Attribution-NonCommercial 4.0 \\ International License.
}

\begin{abstract}
Present study was carried out mainly aiming at studying the effect of non-genetic factors on prolificacy and preweaning kid mortality of Khari goats in Nawalpur, Nepal. The traits were recorded for 1005 does were measured and analyzed using fixed effect Least Square Mixed Model and Maximum Likelihood Computer Program (LSMMML PC-2). Results revealed that overall mean prolificacy and pre-weaning kid mortality in this study were 145 and $6.2 \%$, respectively. According to the results, non-genetic factors such as altitude, coat color and dam's parity were the important sources of variation with respect to pre-weaning kid mortality and prolificacy of Khari goats in this study. Thus, the results of present study suggested the scope of improvement in prolificacy and pre-weaning kid mortality through selective breeding.
\end{abstract}

Keywords: Khari goats, mortality, prolificacy, twinning.

Correct citation: Bhattarai, N. (2021). Effect of non-genetic factors on prolificacy and preweaning kid mortality of Khari goats in Nawalpur, Nepal. Journal of Agriculture and Natural Resources, 4(1), 87-95. DOI: https://doi.org/10.3126/janr.v4i1.33230

\section{INTRODUCTION}

Goats are the important livestock species in Nepalese farming system. Most of the rural population depends on goats for meat, manure, fibre, and pack purposes. Goat contributes in the food and economic security (Bhattarai et al., 2019) and are usually known as cash generating animal during emergency and goat enterprise suitable for landless marginal and small farmers as well (Uperti, 2008). Goat meat production in Nepal ranks second $(20.7 \%)$ after buffalo and shares about 4\% to total GDP (MoALD, 2019). Goats can efficiently survive on available shrubs and trees in adverse harsh environment in low fertility lands where no other crop can be grown (Hagan et al., 2012). There are four prominent indigenous genetic resources of goats in Nepal viz. Chyangra, Sinhal, Khari and Terai (Neopane, 1997). Khari goats are normal with conservation view point and widely preferred goats covering more than 50 percent of small ruminant population in Nepal (Neopane \& Pokharel, 2004; Bhattarai et al., 2019; Poudel, 2020). 
Journal of Agriculture and Natural Resources (2021) 4(1): 87-95

ISSN: 2661-6270 (Print), ISSN: 2661-6289 (Online)

DOI: https://doi.org/10.3126/janr.v4i1.33230

There is a very wider genetic variability among Khari breeds of goats in Nepal in relation to variation in growth, reproductive and morphological traits. They have small body size ranging from 25 to $30 \mathrm{~kg}$ males and $20-25 \mathrm{~kg}$ females with low to medium body length, wither height and heart girth that enables it to survive under stressful environmental conditions, high disease incidence, and low input requiring (Neopane, 1997; Kolachhapati, 2006). Khari goats have little been explained with respect to prolificacy and pre-weaning kid mortality that are considered to be the important selection criteria of within breed selection for genetic improvement of does (Hagan et al., 2012; Salako \& Ngere, 2002). Prolificacy in general is associated with the reproductive functions of an adult does whereas, pre-weaning kid mortality is directly correlated to mothering ability of the lactating does. Based on this facets and figures, present study therefore sought to study the effect of non-genetic factors on prolificacy and preweaning kid mortality of Nepalese indigenous Khari goats in the mid-hills of Nawalpur district, Gandaki Province, Nepal. Thus, present study was mainly focused on determining the baseline values of prolificacy and kid mortality of Khari goats and to study the effect of some nongenetic factors associated to bring variation among these traits.

\section{MATERIALS AND METHODS}

This study was carried out in the indigenous goat flocks of Hupsekot Rural Municipality (former Deurali VDC), Nawalpur, Nepal representing two agro-ecological domains i.e. Inner terai (lower altitude) and hill (upper altitude). Altogether, 1005 adult does were evaluated under farmers managed condition to study the prolificacy and pre-weaning kid mortality. There were altogether three non-genetic factors considered in this study. These non-genetic factors are being described hereunder.

\section{Non-genetic factors considered}

\section{Altitude}

Altitude was an important non-genetic factor affecting the major economic traits of goats. There were two sub-classes of altitude. They were:

a. Lower altitude: Altitude from 300 to 700 masl.

b. Upper altitude: Altitude from700 to 1100 masl.

\section{Coat color}

Coat color of the goats under this study was grouped into five sub-classes. Each subclass is defined as follows:

a. Black: The animals with solid black coat color.

b. Black and white: Animals having black and white patches on the body.

c. Brown: Animals with solid brown coat color.

d. Mixed: Animals having the patches/spots of three or more than three colors on the body.

e. White: Animals having solid white coat color.

\section{Parity of dams}

Parity of dams under this study was grouped under three sub-classes:

a. Early parity: This sub-class consisted of the does having first and second kidding in their lifespan. 
Journal of Agriculture and Natural Resources (2021) 4(1): 87-95

ISSN: 2661-6270 (Print), ISSN: 2661-6289 (Online)

DOI: https://doi.org/10.3126/janr.v4i1.33230

b. Middle parity: The does having third, fourth, fifth and sixth parity.

c. Late parity: The does having seventh and above parity.

\section{Data analysis}

Data were analyzed based on C.R. Henderson model using "Least Square Mixed Model and Maximum Likelihood Computer Program (LSMMML PC-2)” (Harvey, 1990).

$$
Y_{i j k l}=\boldsymbol{\mu}+a_{i}+b_{j}+c_{k}+e_{i j k l}
$$

Where, $Y_{i j k l}=$ adjusted mean for body morphological traits.

$\mu=$ Pooled/overall mean

$a_{i}$ is the effect of $\mathrm{i}^{\text {th }}$ altitude ( $\left.\mathrm{i}=1,2\right)$ : lower and upper.

$b_{j}$ is the effect of $\mathrm{j}^{\text {th }}$ coat color of kids $(\mathrm{j}=1,2,3,4,5)$; black, black and white, brown, mixed and white.

$c_{k}$ is the effect of $\mathrm{k}^{\text {th }}$ number of parity of dams $(\mathrm{k}=1,2,3)$; early, middle and late.

$e_{i j k l}=$ is the random element (residual effect) assumed to be normally and independently distributed.

\section{RESULTS AND DISCUSSION}

\section{Prolificacy (\%) and pre-weaning kid mortality (\%)}

Results of this study revealed that total prolificacy of the Khari does was $145 \%$. At the meantime, findings of present study also indicated that pre-weaning kid mortality within the flock of Khari does was $6.2 \%$.

\section{Effect of parity}

Present findings revealed that prolificacy and pre-weaning kid mortality was varied with respect to the parity of dams (Figure 1). Accordingly, prolificacy percent was observed to be increased with advances parity of dams up to $5^{\text {th }}$ parity and was declined beyond this parity. More or less, a plateaued prolificacy was also observed from $3^{\text {rd }}$ to parity of Khari does. This indicated that, more attention should be paid during these stages of growth for improving reproductive efficiency of the does and highly profitable goat enterprise.

On the other hand, in contrast to the prolificacy, pre-weaning kid mortality was decreased with advancement in the parity of dams up to $6^{\text {th }}$ parity and afterwards, it was increased at increasing rate (Figure 1). Values of both prolificacy and pre-weaning kid mortality in the adjoining Figure 1 indicated that the does of advanced parity will lose their genetic potentials with respect to these traits and is suggested to cull the does reaching to more than $7^{\text {th }}$ parity. 
Journal of Agriculture and Natural Resources (2021) 4(1): 87-95

ISSN: 2661-6270 (Print), ISSN: 2661-6289 (Online)

DOI: https://doi.org/10.3126/janr.v4i1.33230

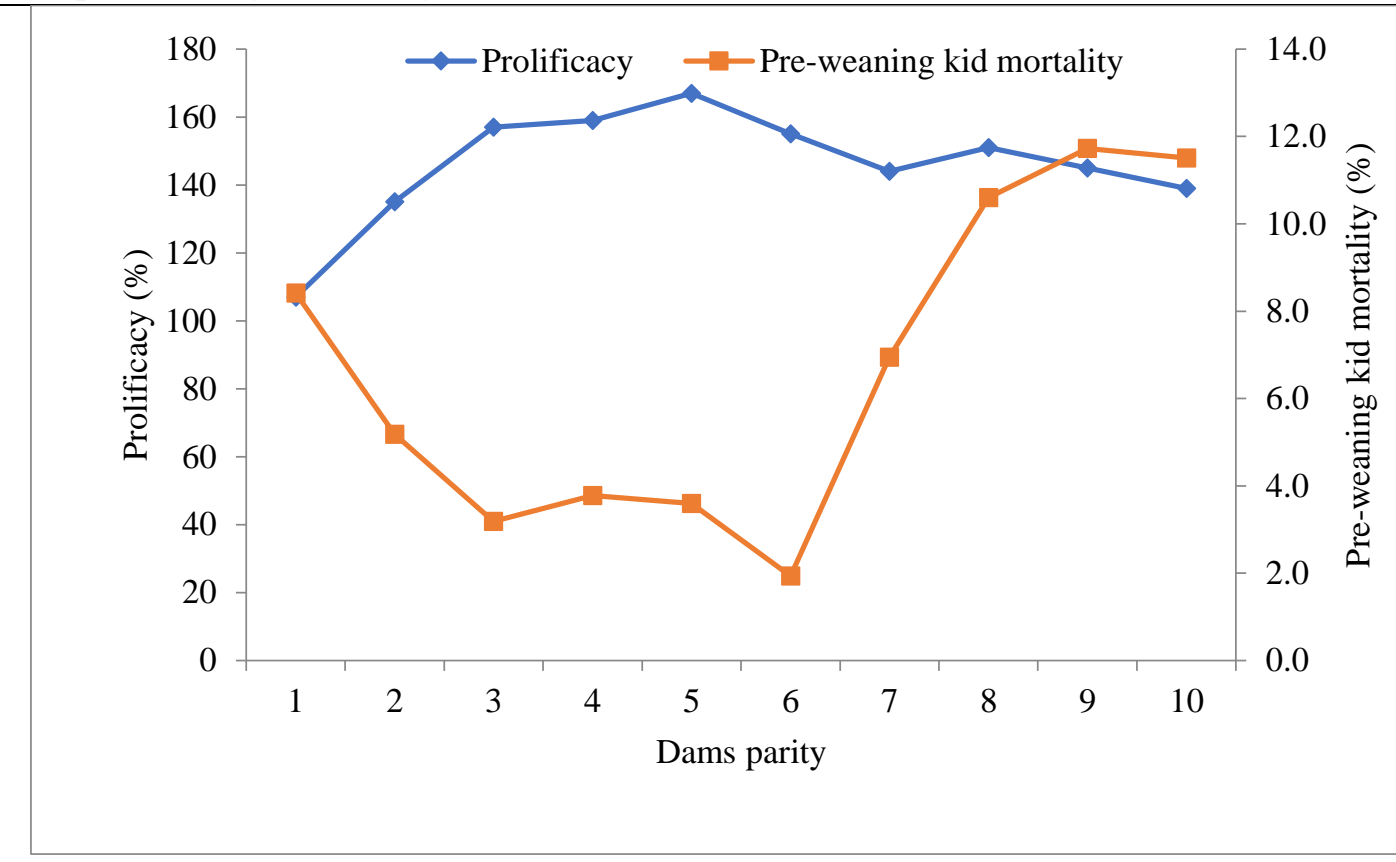

Figure 1. Prolificacy and pre-weaning kid mortality (in \%) with respect to the parity of dams of Khari goats in Nawalpur, Nepal.

\section{Effect of altitude}

Prolificacy and pre-weaning kid mortality was also influenced with the variation in altitude (Figure 2). Accordingly, higher rate of prolificacy and pre-weaning kid mortality was observed for the does of lower altitude and both traits were observed to be declined while moving to the upper altitude. Higher pre-weaning kid mortality $(\%)$ in lower altitude than in upper might be associated with the occurrence/prevalence of higher parasitic loads in lower altitude.

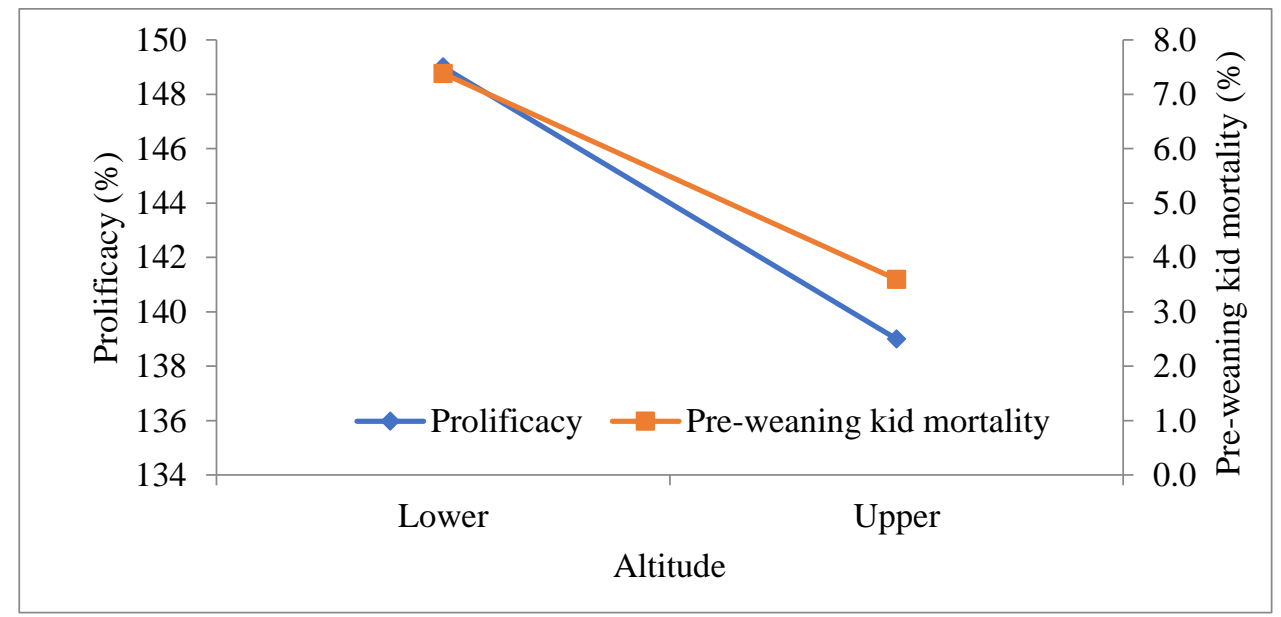

Figure 2. Prolificacy and pre-weaning kid mortality (in \%) of Khari goats with respect to altitude 
Journal of Agriculture and Natural Resources (2021) 4(1): 87-95

ISSN: 2661-6270 (Print), ISSN: 2661-6289 (Online)

DOI: https://doi.org/10.3126/janr.v4i1.33230

\section{Effect of coat color}

Results also revealed that pre-weaning kid mortality was influenced with the variation in their coat color (Figure 2). Accordingly, higher rate of pre-weaning kid mortality was observed for the does of black \& white and mixed colored does. On the other hand, prolificacy was not so affected by the coat color of does (Figure 2). However, black and white colored does had quite lower rate of prolificacy as compared to those of other coat colors.

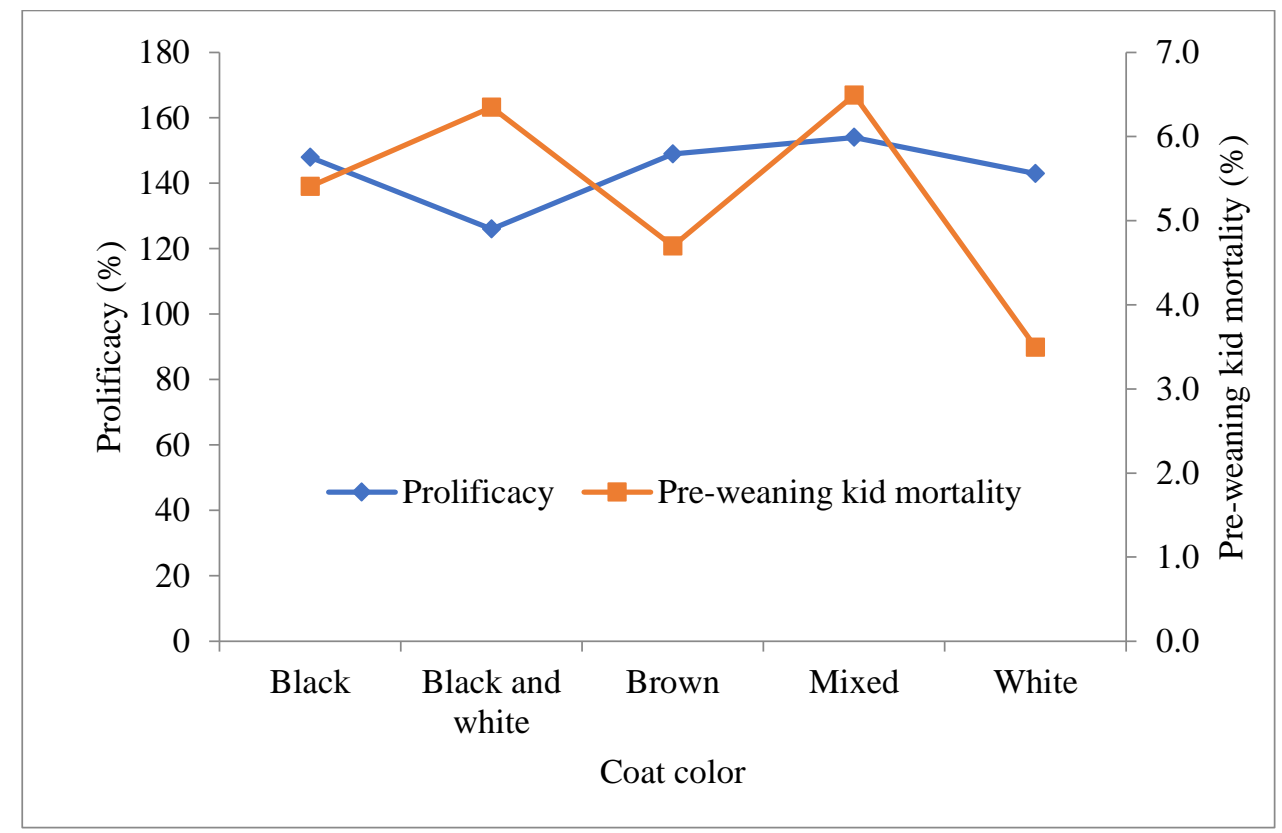

Figure 3. Prolificacy and pre-weaning kid mortality (in \%) with respect to coat color of Khari goats

\section{DISCUSSION}

Kharel and Neopane (1998) opined that in comparison to Nepalese indigenous breeds viz. Chyangra (in mountains), Sinhal (in high hills), and Terai (in Terai), Nepalese Khari (in hills) is one of the most popular breeds for its productivity, prolificacy, twinning ability and adaptively.

\section{Kid mortality}

Bushara et al. (2013) reported the overall average mortality rate of $4.3 \%$ reaching to $9.6 \%$ in rainy season in case of Taggar goats in western Sudan. Al-Najjar et al. (2009) reported the mortality rates at birth and from birth to weaning ranging from $4 \%$ to $24 \%$ and $3 \%$ to $18 \%$, respectively in Shami goats in Damascus, Syria.

Al-Najjar et al. (2009) also reported the significant effect of parity $(\mathrm{P}<0.05)$ on mortality rates at birth and from birth to weaning. This might be due to an age effect; as dams increased in maturity the survival rate of kids improved. Results of present study are in agreement with the findings of Mazumdar et al. (1980) using Pashmina goats and kids, and Barding et al. (2000) 
Journal of Agriculture and Natural Resources (2021) 4(1): 87-95

ISSN: 2661-6270 (Print), ISSN: 2661-6289 (Online)

DOI: https://doi.org/10.3126/janr.v4i1.33230

working with Osmanabadi goats; but in disagreement with the results of Mandonnet et al. (2003) who worked with Creole goats.

According to Deribe et al. (2014) parity has significant effect ( $\mathrm{p}<0.01)$ on preweaning mortality rates of kids. Accordingly, mean pre weaning mortality rate was $12.59 \%$. Similarly, Berhan and Arendonk (2006), reported that under uncontrolled breeding conditions the mortality rate was $15 \%$ and Goonewardene et al. (1998) reported preweaning mortality was $9.4 \%$.

Tesema et al. (2017) reported that the pre weaning mortality was about $24.2 \%$ in Central Highland x Boer crossbred goats in North Eastern Ethiopia. Similarly, Preweaning mortality rate of Borana and Arsi-Bale breed was $43 \%$ and $25 \%$ respectively and Hailu et al. (2006) reported that parity was an important source of variation with respect to preweaning kid survival. Gradual decrease in pre-weaning mortality rate to the fourth parity thereafter it elevates. Accordingly, preweaning mortality was highest $(77 \%)$ with advanced parity $\left(6^{\text {th }}\right.$ parity). Average pre-weaning mortality rate for South African Angora goats was reported to be 11.5 (range 8.6-16.5\%) (Snyman, 2010). Early neonatal kid mortality was reported to be 7.5\% by Sharif et al. (2005) due to different causes in Jordan. Donkin and Boyazoglu, (2004) reported that the mean annual goat kid mortality was $29 \%$. Similarly, overall preweaning kid mortality for different breeds of Israel and Sinai was17.81\% (Rattner et al., 1994).

\section{Prolificacy}

Khari breed has its prominent characteristics of high prolificacy i.e. 1.83 (Pradhan \& Gurung 1985). According to Crepaldi et al. (1999) Parity had significant effect ( $\mathrm{p}<0.001)$ on prolificacy with mean of 1.2, 1.5 and 1.7 kids in first, second and fourth parity then with advanced parity no. kids/kidding decreases.

Haldar et al. (2014) reported that the average litter size of Black Bengal goats as 1.75 in a study was quite comparable with some world prolific goat breeds including Nubian, Pygmy, American Alpine, French Alpine, Saanen and Toggenburg with the average litter size of 2.0, $1.9,1.9,1.7,1.7$ and 1.6, respectively. These findings suggests that Nepalese indigenous Khari goats are prolific goat breed.

\section{CONCLUSIONS}

In conclusion there is wider variation in prolificacy and pre-weaning kid mortality existed within the flock of Khari does. Parity of dams, altitude and coat color of the animals were the major sources of variation with respect to the prolificacy of the does and pre-weaning mortality of kids. Prolificacy percent increases with increase in parity up to $5^{\text {th }}$ parity and the declines beyond this parity in contrast, pre-weaning kid mortality decreases with advancement in the parity of dams up to $6^{\text {th }}$ parity and afterwards. Upper altitude is suitable for Khari as compared to lower altitude since there is substantially lower pre-weaning kid mortality in these regions.

\section{ACKNOWLEDGEMENTS}

The author expresses sincere thanks and heartfelt gratitude to University Grants Commission (UGC), Sanothimi, Bhaktapur for partial financial assistance for this piece of work. Directorate of Research and Extension (DOREX) and Faculty of Animal Science, Veterinary Science and 
Journal of Agriculture and Natural Resources (2021) 4(1): 87-95

ISSN: 2661-6270 (Print), ISSN: 2661-6289 (Online)

DOI: https://doi.org/10.3126/janr.v4i1.33230

Fisheries under Agriculture and Forestry University are highly acknowledged for the constant technical and administrative facilitation for this scientific work. Most importantly, Prof. Dr. Manaraj Kolakshyapati, Prof. Dr. Naba R. Devkota, Dr. Shreeram P. Neopane, Uday C. Thakur, Neena A. Gorkhali, and Saroj Sapkota are specially acknowledged for their everlasting support and cooperation during the course of this study. Participant farmers of Hupsekot Rural Municipality, Deurali, Nawalparasi are highly appreciated and sincerely acknowledged for their constant and selfless support during the entire period of field experiment.

\section{Author's Contribution}

NB conceived, designed and performed experiments, collected and analyzed data and drafted the manuscript, revised it and finalized the paper.

\section{Conflicts of Interest}

The author declares that there is no conflict of interest.

\section{REFERENCES}

Al-Najjar, K., Salhab, S., Al-Merestani, R., Kasem, R., Al-Azzawi, W., Dawa, M., \& Saatci, M. (2009). Environmental Factors Affecting Damascus Goats Capricorn Deaths. Journal of Kafkas University Faculty of Veterinary Medicine, 16(3), 431-435.

Barding R. P., Mohite, P.M., Patil, G.R., \& Dhoble, R.L. (2000). Effect of season on kidding birth weight and pre-weaning mortality in Osmanabadi goats. Proceedings of $7^{\text {th }}$ International Conference on Goats, 1521 May, France.

Berhan, A., \& Arendonk, J. Van. (2006). Reproductive performance and mortality rate in Menz and Horro sheep following controlled breeding in Ethiopia. Small Ruminant Research, 63, 297-303. DOI: https://doi.org/10.1016/j.smallrumres.2005.03.003

Bhattarai, N., Gorkhali, N. A., Kolakshyapati, M.R., \& Sapkota, S. (2019). Breeds and Breeding System of Indigenous and Crossbred Goats in Nepal. In Goats (Capra). IntechOpen. DOI: http://dx.doi.org/10.5772/intechopen.82821

Bushara, I., O. Abdelhadi, M.A. Elemam, M.B., Idris, A.O., Mekki, D.M., Ahmed, M.M., \& Abu Nikhiala, A.M. (2013). Effect of season of birth and litter size on Taggar goat's production in western Sudan. Wudpecker Journal of Agricultural Research, 2(4), 128 $-133$.

Crepaldi, P., Corti, M., \& Cicogna, M. (1999). Factors affecting milk production and prolificacy of Alpine goats in Lombardy (Italy). Small Ruminant Research, 32(1), 8388. DOI: https://doi.org/10.1016/S0921-4488(98)00156-4

Deribe, G., Abebe, G., \& Tegegne, A. (2014). Non-genetic factors influencing reproductive traits and pre- weaning mortality of lambs and kids under smallholder management, southern ethiopia. The Journal of Animal \& Plant Sciences, 24(2), 413-417.

Donkin, E. F., \& Boyazoglu, P. A. (2004). Diseases and mortality of adult goats in a South African milk goat herd. South African Journal of Animal Sciences, 34(1). 254-257.

FAO (2020). Domestic animal diversity information system. Rome. (available at http://www.fao.org/dad-is/). Retrieved on $14^{\text {th }}$ August, 2020.

Goonewardene, L. A., Day, P. A., Patrick, N., Scheer, H. D., Patrick, D., \& Suleiman, A. (1998). A preliminary evaluation of growth and carcass traits in Alpine and Boer goat 
Journal of Agriculture and Natural Resources (2021) 4(1): 87-95

ISSN: 2661-6270 (Print), ISSN: 2661-6289 (Online)

DOI: https://doi.org/10.3126/janr.v4i1.33230

crosses. Canadian Journal of Animal Science, 78(2), 229-232.
https://doi.org/10.4141/A97-041

Hagan, J.K., Apori, S.O., Bosompem, M., Ankobea, G., Mawuli, A., \& Al-Hagan, E.T. (2012). Morphological Characteristics of Indigenous Goats in the Coastal Savannah and Forest Eco-Zones of Ghana. J Anim Sci Adv., 2(10), 813-821.

Hailu, D., Mieso, G., Nigatu, A., Fufa, D., \& Gamada, D. (2006). The effect of environmental factors on preweaning surival rate of Borana and Arsi-Bale kids. Small Ruminant Research, 66(1-3), 291-294. https://doi.org/10.1016/j.smallrumres.2005.09.024

Haldar, A., Pal, P., Datta, M., Paul, R., Pal, S. K., Majumdar, D., ... \& Pan, S. (2014). Prolificacy and its relationship with age, body weight, parity, previous litter size and body linear type traits in meat-type goats. Asian-Australasian journal of animal sciences, 27(5), 628.

Harvey, W.R.(1990). Users' Guide for LSMLMW and MIXMDL. PC-2 Version. Mixed Model Least Squares and Maximum Likelihood Computer Program.

Kharel, M., \& Neopane, S.P. (1998). Goat genetic resources. In: Proceedings of the $1^{\text {st }}$ National Workshop on Animal Genetic Resources Conservation and Genetic Improvement of Domesticated Animals in Nepal. (Editor: JNB Shrestha). Nepal Agricultural Research Council (NARC). 48-54, Kathmandu, P O Box 5459, Nepal.

Kolachhapati, M.R. (2006). Phenological study of hill goats under different management systems and nutritional regimes. (Unpublished doctoral dissertation). Institute of Agriculture and Animal Sciences, Tribhuvan University, Nepal. 148p.

Kolachhapati, M.R. (2012). Entrepreneurial goat production in the eastern mid-hills and Terai region of Nepal. Technical Publication. National Agricultural Research and Development Fund (NARDF), Singhdurbar Plaza, NARC Building, Kathmandu, Nepal.

Kolachhapati, M.R., Bhattarai, N, \& Devkota, NR. (2012), Goat Research Initiatives at IAAS Nepal. Proceedings of the National Workshop on Research and Development Strategies for Goat Enterprises in Nepal. Pp.182-187.

Mandonnet, N., Ducrocq, V., Arquet, R., \& Aumont, G. (2003). Mortality of Creole kids during infection with gastrointestinal strongyles a survival analysis. J Anim Sci, 81, 2401-2408.

Mazumdar N.K., Mazumdar, A. and Goswami, K.K. (1980). Studies on some factors affecting mortality and survival rates in Pashmina kids. Indian J Anim Sci, 50, 251-255.

MoALD. (2019). Statistical Information on Nepalese Agriculture. Agri-business Promotion and Statistics Division (ABPSD), Ministry of Agriculture and Livestock Development (MoALD), Singh Durbar, Kathmandu, Nepal.

Neopane, S. P., \& Pokharel, P.K. (2004). Genetic gain in selected herds of Khari goats over generations in Nepal. Pp.1-7.

Neopane, S.P. (1997). Genetics of productive traits in a Nepalese Hill goat flock. (Unpublished doctoral dissertation). University of London, UK. 278p.

Nepali, M. B., Tiwari, M. R., Sapkota, S., Poudel, H. P., Acharya, B. R., \& Gautam, S. (2014). Marketing Constraints to Goats in the Western Hill of Nepal. Nepal Agriculture Research Journal, 8, 95-102. https://doi.org/10.3126/narj.v8i0.11601

Neupane, N., Neupane, H., \& Dhital, B. (2018). A Socioeconomic View of Status and Prospects of Goat Farming in Rural Areas of Nepal. Journal of the Institute of Agriculture and Animal Science, 35(1), 1-8. DOI: https://doi.org/10.3126/jiaas.v35i1.22508 
Journal of Agriculture and Natural Resources (2021) 4(1): 87-95

ISSN: 2661-6270 (Print), ISSN: 2661-6289 (Online)

DOI: https://doi.org/10.3126/janr.v4i1.33230

Poudel, J.R. (2020). Evaluation of Boer Cross with Different Breeds of Goat in Surkhet, Nepal. (Unpublished master thesis). Agriculture and Forestry University, Rampur, Chitwan, Nepal.

Pradhan, S.L., \& Gurung, N.K. (1985). Comparative performance of Khari (Local Hill) goat and its crossbreds with Jamunapari goat at Central Goat Farm, Bandipur. Nepalese Journal of Animal Science, 1, 35-45.

Rattner, D. Riviere, J., \& Bearman, J. E, (1994). Factors affecting abortion, stillbirth and kid mortality in the Goat and Yaez (Goat $\times$ ibex). Small Ruminant Research, 13(1), 33-40. DOI: https://doi.org/10.1016/0921-4488(94)90028-0

Salako, A.E., \& Ngere, L.O. (2002). Application of multifactorial discriminant analysis in the morphometric structural differentiation of West African Dwarf (WAD) and Yankasa sheep in South West Nigeria. Nigerian Journal of Animal Production, 29,163-167.

Sharif, L., Obeidat, J., \& Al-Ani, F. (2005). Risk factors for lamb and kid mortality in sheep and goat farms in Jordan. Bulgarian Journal of Veterinary Medicine, 8(2), 99-108.

Snyman, M. A. (2010). Factors affecting pre-weaning kid mortality in South African Angora goats. South African Journal of Animal Sciences, 40(1), 54-64. https://doi.org/10.4314/sajas.v40i1.54128

Tesema, Z., Tilahun, M., Deribe, B., Lakew, M., Belayneh, N., Zegeye, A., \& Aychew, D. (2017). Effect of non-genetic factors on pre-weaning growth, survivability and prolificacy of Central Highland x Boer crossbred goats in North Eastern Ethiopia. Livestock Research for Rural Development, 29(7).

Upreti, C. R. (2008). Food Security Contribution and Vision of Sustainable Goat Production in Nepal. Agricultural research for poverty alleviation and livelihood enhancement. Proceedings of the Third SAS-N Convention. 299-303. 